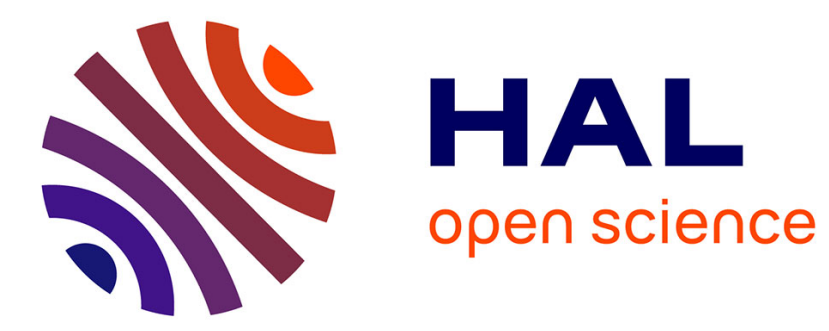

\title{
Dysferlin Exon 32 Skipping in Patient Cells
}

Florian Barthelemy, Sebastien Courrier, Nicolas Lévy, Martin Krahn, Marc

Bartoli

\section{To cite this version:}

Florian Barthelemy, Sebastien Courrier, Nicolas Lévy, Martin Krahn, Marc Bartoli. Dysferlin Exon 32 Skipping in Patient Cells. Exon Skipping and Inclusion Therapies, 1828, pp.489-496, 2018, 10.1007/978-1-4939-8651-4_31. hal-02000829

\section{HAL Id: hal-02000829 \\ https://hal-amu.archives-ouvertes.fr/hal-02000829}

Submitted on 31 Jan 2019

HAL is a multi-disciplinary open access archive for the deposit and dissemination of scientific research documents, whether they are published or not. The documents may come from teaching and research institutions in France or abroad, or from public or private research centers.
L'archive ouverte pluridisciplinaire HAL, est destinée au dépôt et à la diffusion de documents scientifiques de niveau recherche, publiés ou non, émanant des établissements d'enseignement et de recherche français ou étrangers, des laboratoires publics ou privés. 


\title{
Chapter 31
}

\section{Dysferlin Exon 32 Skipping in Patient Cells}

\section{Florian Barthélémy, Sébastien Courrier, Nicolas Lévy, Martin Krahn, and Marc Bartoli}

\begin{abstract}
Dysferlinopathies are rare genetic diseases affecting muscles due to mutations in DYSF. Exon 32 of DYSF has been shown to be dispensable for dysferlin functions. Here we present a method to visualize the skipping of exon 32 at the RNA and protein levels using an antisense oligonucleotide on cells derived from a dysferlinopathy-affected patient.
\end{abstract}

Key words Dysferlin, Exon skipping, Muscular dystrophies, Therapies, RNA editing

\section{Introduction}

Exon skipping has been a tremendous breakthrough in the field of RNA therapeutics. First use for beta-thalassemia, exon skipping has rapidly been tested in the field of rare disease where no treatment is currently available. Therefore, it has been firstly tested on lymphoblastoid cell lines from a boy affected with Duchenne muscular dystrophy $[1,2]$ and as the technique seemed promising, numerous studies have been published using this technology in various cell types and in a large cohort of diseases including other neuromuscular diseases, cystic fibrosis or cancer (for review see [3]). Exon skipping is mainly investigated for removing or including one or more exons to restore the reading frame in a context of a deletion or duplication. Other applications are also explored but are limited by the number of patients that can benefit from it (point mutations, mutations leading to the activation of a cryptic splice site, insertion of a pseudo exon, ...) and will unlikely be translated to the clinic. Here we give an overview of the strategy employed to restore functionality in dysferlin-deficient cell lines. We based our work on the use of 2'OMethyl-Phosphorothioate modified antisense oligonucleotides (AON) since this chemistry is more easily uptakes by the cells in comparison to phosphorodiamidate 
morpholino oligomer. The choice of dysferlin exon 32 was based on the report from Sinnreich and colleagues of a patient with a very mild and late onset phenotype associated to a natural skipping of exon 32 [4]. We demonstrated an efficient exon 32 skipping using AON in myotubes generated from MyoD-transduced fibroblasts cell lines derived from a control and a patient [5]. In the dysferlin context, the levels of exon skipping at the messenger RNA (mRNA) level do not necessarily correlate with the amount of protein visualized by western blot making harder to analyze the efficiency of the strategy. However, despite the relatively low abundance of protein in a given population of cells, it appears evident now that some cells are able to produce proteins to a physiologically relevant level that partially restore functionality [6]. Based on a repeated administration of the $\mathrm{AON}$, three times a week, we can visualize a restoration of dysferlin at the protein level [6]. After treatment, the ability of the cells to respond to different kinds of membrane stresses is of particular interest since one of the main roles of dysferlin is promoting membrane repair mechanisms [7]. The importance of demonstrating that a partial protein rescue is efficient to restore specific functions of dysferlin is therefore crucial. Here we present a step-by-step process to induce DYSF exon 32 skipping using a specific AON and its validation at mRNA and protein levels.

\section{Materials}

\subsection{Myoblasts Cell Culture}

2.2 Exon Skipping
1. Skeletal Muscle Cell Growth Medium (Promocell \#C23060) ( see Note 1).

2. Skeletal Muscle Cell Differentiation Medium (Promocell \#C23061).

3. DPBS, no calcium, no magnesium.

4. Antibiotic antimycotic $100 \times$ solution (Ge Healthcare ref. P11-002).

5. Trypsin-EDTA (0.05\%) (ThermoFisher Scientific\# 25300054).

6. Fetal bovine serum.

1. Oligofectamine (ThermoFisher Scientific \#12252-011) (see Note 2).

2. DMEM, high glucose, GlutaMAX ${ }^{\mathrm{TM}}$ Supplement (ThermoFisher Scientific \# 61965026).

3 . Resuspend the $2^{\prime} \mathrm{O}$-methyl antisense oligonucleotides $(\mathrm{AON})$ in TE pH 7.0. Aliquot and place at $-20{ }^{\circ} \mathrm{c}$ ( see Note 3$)$.

4. Purelink RNA extraction kit (ThermoFisher Scientific \# 12183020). 
5. DNAse I (RNase free) (ThermoFisher Scientific. \#AM1906).

6. Primers IF 5' - ATGGAGCCACTGGaGAaGAC - $3^{\prime}$ 3R 5' AGGGTGTTCTTCACCACCAC - 3'.

7. AON: 5'-GCGUAGAUGGUAGCGGUUCCC- ${ }^{\prime}$.

8. Scrambled AON: 5'-GGAUCCCGCUCAGGAGUGCUG-3'.

9. SuperScript ${ }^{\mathrm{TM}}$ One-Step RT-PCR System with Platinum ${ }^{\mathrm{TM}}$ Taq DNAPolymerase (ThermoFisher Scientific \#10928-034).

10. Ultrapure water.

11. NanoDrop1000 (ThermoFisher Scientific).

\subsection{Western Blot}

1. Lysis Buffer $2 \times$ : $4 \%$ SDS, $0.02 \%$ bromophenol blue, $20 \%$ glycerol-tris pH 6.8, $100 \mathrm{mM}$ EDTA.

2. 2-Mercaptoethanol.

3. NuPAGE reducing agent $10 \times$ (ThermoFisher Scientific \#NP0009).

4. Transfer buffer: $4.84 \mathrm{~g}$ of tris base, $22.52 \mathrm{~g}$ of glycine, $400 \mathrm{~mL}$ of ethanol 200 proof, $0.02 \%$ SDS filled to $2 \mathrm{~L}$ with water (see Note 4).

5. Blocking solution: TBS $+1 \%$ of nonfat milk.

6. Wash solution; TBS $+0.1 \%$ Tween 20 .

7. Hamlet Dysferlin [Haml/7B6] (Abcam \#ab75571).

8. Peroxidase AffiniPure $\mathrm{F}(\mathrm{ab}$ '), Fragment Donkey Anti-Mouse $\operatorname{IgG}(\mathrm{H}+\mathrm{L})$ (Jackson Immuno Research \#715-036-15).

9. Luminata forte (Millipore \#WBLUF0100).

\section{Methods}

\subsection{Antisense \\ Oligonucleotide Transfection}

1. Cultivate cells in Skeletal Muscle Cell Growth Medium until confluent (see Note $\mathbf{1}$ ).

2. When cells have reached confluence, switch to Skeletal Muscle Cell Differentiation Medium, after a wash in PBS.

3. Fourty eight hours after differentiation, proceed to transfection using Oligofectamine as followed (for a T $75 \mathrm{~cm}^{2}$ flask) ( see Note 5):

- $\quad$ Mix in a $1.5 \mathrm{~mL}$ eppendorfs $64 \mu \mathrm{L}$ of Oligofectamine and $64 \mu \mathrm{L}$ of DMEM. Briefly vortex. Wait $5 \mathrm{~min}$ at room temperature (see Note 1).

- Mix $64 \mu \mathrm{L}$ of AON (at $100 \mu \mathrm{M}$ ) with $720 \mu \mathrm{L}$ of DMEM. Briefly vortex and spin.

- Combine both mix in one tube. Briefly vortex and spin. Wait $20 \mathrm{~min}$ at room temperature. 


\subsection{RNA Extraction and Reverse Transcription}

- During the incubation time, wash cells with PBS prior to adding $6.4 \mathrm{~mL}$ of DMEM per flask.

- After the incubation time, dispatch the mix by dropping it gently in the flask. Place in the $\mathrm{CO}_{2}$ incubator at $37^{\circ} \mathrm{C}$ for $4 \mathrm{~h}$.

- After $4 \mathrm{~h}$, add $8 \mathrm{~mL}$ of Skeletal Muscle Cell Differentiation Medium and place back into the $\mathrm{CO}_{2}$ incubator at $37^{\circ} \mathrm{C}$.

4. Twenty four hours after transfection, replace the media with $10 \mathrm{~mL}$ of fresh Skeletal Muscle Cell differentiation Medium.

5. Fourty eight hours after transfection, harvest cells for RNA extraction and Western Blot. Cells are first washed with PBS and then incubated for $5 \mathrm{~min}$ in the $\mathrm{CO}_{2}$ incubator at $37^{\circ} \mathrm{C}$ with EDTA-trypsin. After 5 min add a mix of PBS-FBS (7/1). Collect the cells into a $15 \mathrm{~mL}$ falcon tube and centrifuge for 5 min at $200 \times g$.

6. After centrifugation, cells are resuspended in $10 \mathrm{~mL}$ PBS and split in three tubes as followed: $1 \mathrm{~mL}$ for RNA extraction and 2 tubes containing $4.5 \mathrm{~mL}$ of cell suspension for protein extraction. After splitting, cells are spin at $200 \times g$ for 5 min and kept in $-80{ }^{\circ} \mathrm{C}$ as a dry cell pellet ( see Note 6 ).

1. Transfer the frozen cell pellet to an RNase-free tube, then add $500 \mu \mathrm{L}$ of TRIzol $5 \mathrm{~min}$ at room temperature. Pass the suspension through a syringe (see Note 7).

2. Add $100 \mu \mathrm{L}$ of chloroform solution directly in the TRIzol suspension; keep 2-3 min at room temperature.

3. Centrifuge at $12,000 \times g$ for $15 \mathrm{~min}$ at $4{ }^{\circ} \mathrm{C}$.

4. Transfer the aqueous phase to a clean RNase-free tube. Add one volume $70 \%$ ethanol to each volume of cell homogenate to have a final concentration of $35 \%$ ethanol. Then vortex and invert 2-3 times.

5. Transfer up to $700 \mu \mathrm{L}$ of the sample (including any remaining precipitate) to the Spin Cartridge.

6. Centrifuge at $12,000 \times g$ for $15 \mathrm{~s}$ at room temperature.

7. Discard the flow-through and reinsert the Spin Cartridge into the same tube.

8. Add $700 \mu \mathrm{L}$ Wash Buffer I to the Spin Cartridge.

9. Centrifuge at $12,000 \times g$ for $15 \mathrm{~s}$ at room temperature.

10. Discard the flow-through and tubes. Place the Spin Cartridge into a new tube ( see Note 8).

11. Add $500 \mu \mathrm{L}$ Wash Buffer II with ethanol to the Spin Cartridge.

12. Centrifuge at $12,000 \times g$ for $15 \mathrm{~s}$ at room temperature. 
13. Discard the flow-through and reinsert the Spin Cartridge into the same tube.

14. Repeat the last step once.

15. Centrifuge the Spin Cartridge at $12,000 \times g$ for 1 min to dry the membrane with attached RNA.

16. Discard the tube and insert the Spin Cartridge into a new tube.

17. Add $30 \mu \mathrm{L}$ RNase-Free Water to the center of the Spin Cartridge, incubate at room temperature for $1 \mathrm{~min}$ ( see Note 9).

18. Centrifuge the Spin Cartridge for $2 \mathrm{~min}$ at $\geq 12,000 \times g$ at room temperature to elute the RNA from the membrane into the tube.

19. Repeat the last step once with the same water (see Note 10).

20. Incubate at room temperature for $5 \mathrm{~min}$ and then dose RNA concentration with the NanoDrop1000 (see Notes 11 and 12).

21. Add $5 \mu \mathrm{L} 10 \times$ DNase I Buffer and $1 \mu \mathrm{L}$ rDNase I to the RNA, and mix gently add $30 \mu \mathrm{L}$ of RNA adjusted with ultrapure water to a final volume of $50 \mu \mathrm{L}$, incubate at $37{ }^{\circ} \mathrm{C}$ for 20-30 min.

22. Add $5 \mu \mathrm{L}$ of DNase inactivation reagent; incubate for $2 \mathrm{~min}$ at room temperature ( see Note 13).

23. Centrifuge at $10.000 \times g$ for $1.5 \mathrm{~min}$ and transfer the RNA to a fresh RNase-free tube.

24. After DNAse treatment, we perform a one step procedure including the Reverse transcription and the PCR using our primers $1 F-3 R$.

(a) Buffer $2 \times 25 \mu \mathrm{L}$.

(b) Template RNA 500 ng.

(c) Sense primer $1 F(10 \mu \mathrm{M}) 1 \mu \mathrm{L}$.

(d) Anti-sense Primer 3R $(10 \mu \mathrm{M}) 1 \mu \mathrm{L}$.

(e) RT/Platinum Taq mix $1 \mu \mathrm{L}$.

(f) Ultrapure water up to a final volume of $50 \mu \mathrm{L}$.

25. The program used is as followed: one step at $50{ }^{\circ} \mathrm{C}$ for $30 \mathrm{~s}$, followed by a quick denaturation at $94{ }^{\circ} \mathrm{C}$ for $2 \mathrm{~min}$. Then 40 cycles of a three steps amplification procedure are performed $\left(94{ }^{\circ} \mathrm{C} 15 \mathrm{~s} .59^{\circ} \mathrm{C} 30 \mathrm{~s}\right.$ and $\left.72{ }^{\circ} \mathrm{C} 1 \mathrm{~min}\right)$. A final amplification step of $7 \mathrm{~min}$ is added. After completion, PCR products are visualized on a $2 \%$ agarose gel and visualized using alpha Innotech imager (see Note 14) (see Fig. I panel a). 
a

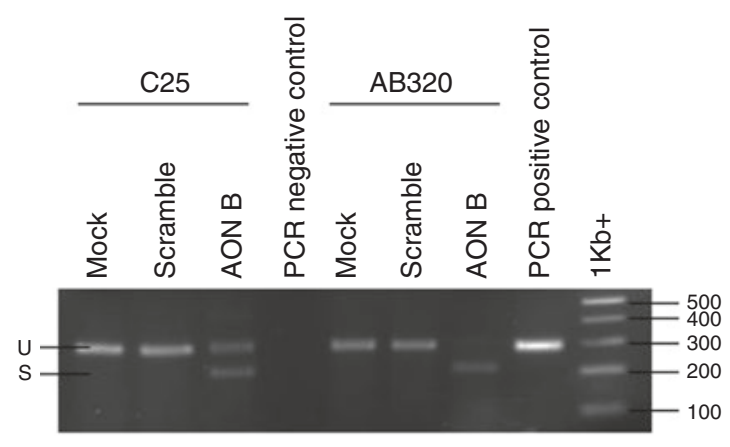

b

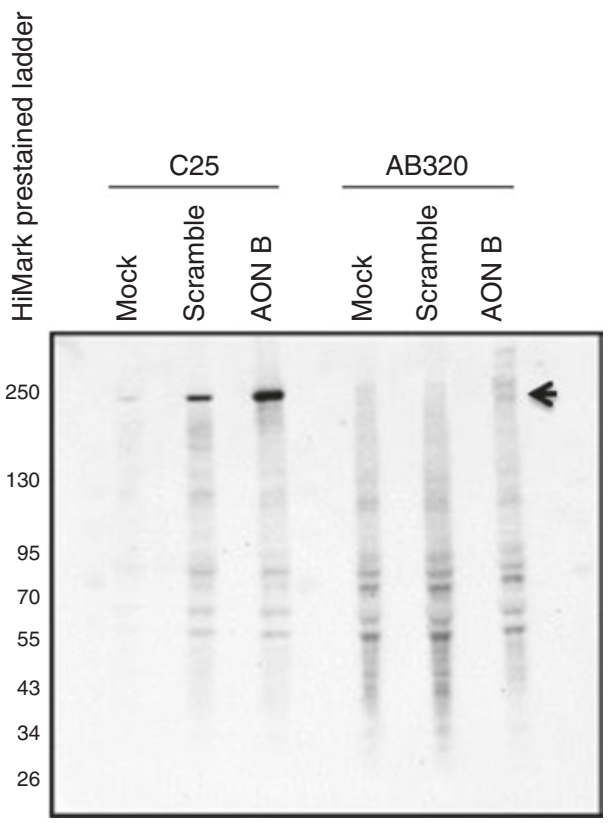

Fig. 1 Validation of exon skipping by RT-PCR and western blot control cell line (C25) and patient-derived cell line were transfected with a specific AON, a scrambled AON or without AON (Mock) before analysis by RT-PCR (panel a) for the presence of skipped (S) and unskipped (U) transcripts. The same conditions were analyzed by western blot using Hamlet antibody for the detection of dysferlin (panel b)

\subsection{Western Blot}

1. The cell pellet is extemporaneously resuspended in $50 \mu \mathrm{L}$ of lysis buffer $2 \times$ in which we add $5 \mu \mathrm{L}$ of beta-mercaptoethanol and $5 \mu \mathrm{L}$ of NUPAGE reducing agent (see Note $\mathbf{1 5}$ ).

2. After a $10 \mathrm{~min}$ incubation at $100^{\circ} \mathrm{C}$ cells are centrifuged $5 \mathrm{~s}$ at $12,000 \times g$ to bring down the condensate.

3. $20 \mu \mathrm{L}$ of samples are then loaded on a $4-12 \%$ MOPS precast gels and run for $30 \mathrm{~min}$ at $80 \mathrm{~V}$ and then $100 \mathrm{~V}$ until the dye front (from the BPB dye in the samples) reached the bottom of the gel.

4. After electrophoresis, open the cast using a spatula, with the gel remaining on one of the parts. Rinse the gel with distilled water and transfer carefully to a container with western blot transfer buffer.

5. A PVDF membrane of the gel size is then activated in methanol, rinse twice in ultrapure water and place in the container with western blot transfer buffer.

6. Flip the gel into two Whatman \# 3-filter cut to the size of the gel. Place the PVDF membrane on top of the gel and followed by two Whatman \# 3 filter paper cut similarly. Place this assemblage in a prewarmed humidified plastic container with a sponge in each side of the sandwich. Place the sandwich in the tank and run for $3 \mathrm{~h}$ at $100 \mathrm{~V}$ at $4{ }^{\circ} \mathrm{C}$. 
7. After transfer, the membrane is then readjusted to the size of the gel edges. The membrane is then placed in blocking solution for half an hour. Hamlet antibody (1:200 dilution) (see Note 16) is then incubated on the membrane for $2 \mathrm{~h}$ with constant motion.

8. Then wash $3 \times$ with TBS $1 \times+0.1 \%$ Tween 20 and incubate with secondary antibody (1:2000 dilution) in blocking buffer $+0.1 \%$ Tween-20 for $45 \mathrm{~min}$ with constant motion. Then wash $3 \times$ with TBS $1 x+0.1 \%$ tween 20 prior to visualization with luminata forte reagent using Biorad Imager (see Note 17) (see Fig. I panel b).

\section{Notes}

1. Other media may be used but after testing, it appears that this media was the only one giving us a stable undifferentiated cell culture.

2. Other transfection reagents/methods may be used but the use of Oligofectamine gives us the best results

3. Antisense oligonucleotides can be resuspended in ultrapure water if stored for a short-term period, but it is preferable to use TE $\mathrm{pH} 7.0$ for a long-term storage. To avoid multiple thawing-freezing cycles consider small aliquots.

4. All solutions should be prepared using ultrapure and analytical grade reagents. All reagents are made and stored at room temperature (unless indicated otherwise).

5. Here we can optimize the protocol by trying Opti-MEM I Reduced Serum Medium (ThermoFisher Scientific \#31985070) instead of DMEM.

6. Here, the cell pellets can be used right away for the subsequent procedures but should be kept at $-80{ }^{\circ} \mathrm{C}$ for a long-term storage.

7. The cell pellet is usually passed through the syringe up and down several times (up to 3 times) in order to break down the cells.

8. At this step, you can also treat the pellet with the on-column DNAseI (ThermoFisher Scientific \#12185010).

9. The total volume of water can be adjusted depending on the amount of starting material. We found that our best results were obtained using volumes comprise between 15 and $30 \mu \mathrm{L}$ of ultrapure water.

10. We found that we increase our RNA concentration by eluting the sample a second time using the same water. 
11. We let the samples for $5 \mathrm{~min}$ to allow sample to homogenize at room temperature and they are always kept on ice after that.

12. We use the Nanodrop 1000 but alternative options exist to measure the concentration of RNA like the Qubit3.0 (ThermoFisher Scientific).

13. This procedure should only be used if you do not do DNAse I column treatment (see Note 8).

14. The ratio of skipping could be calculated by quantifying the ratio of integrated density (obtained via ImageJ software) of the skipped band versus skipped + unskipped bands.

15. 2-mercaptoethanol needs to be manipulated under a chemical hood according to your laboratory regulations.

16. Hamlet antibody is a mouse monoclonal IgGl serotype directed against a synthetic peptide: exon 53 (1999-2016) of human dysferlin.

17. The exon 32 deleted dysferlin band is shorter (26 amino acid less) than the wild type form of dysferlin (expected size $230 \mathrm{kDa})$.

\section{Acknowledgment}

The work was supported by grant from INSERM, Aix Marseille Univ, Association française contre les myopathies, Neuromics FP7 program E.U. (2012-305121). F.B. has received a postdoc fellowship grant from the UCLA Center for Duchenne Muscular Dystrophy-NIH NIAMS U54 AR052646 Wellstone Center of Excellence Training Fellowship respectively.

\section{References}

1. Dominski Z, Kole R (1993) Restoration of correct splicing in thalassemic pre-mRNA by antisense oligonucleotides. Proc Natl Acad Sci U S A 90(18):8673-8677

2. Pramono ZA, Takeshima $\mathrm{Y}$, Alimsardjono $\mathrm{H}$ et al (1996) Induction of exon skipping of the dystrophin transcript in lymphoblastoid cells by transfecting an antisense oligodeoxynucleotide complementary to an exon recognition sequence. Biochem Biophys Res Commun 226(2):445-449

3. van Roon-Mom WM, Aartsma-Rus A (2012) Overview on applications of antisense-mediated exon skipping. Methods Mol Biol 867:79-96. "https://doi.org/10.1007/978-1-61779767-5_6"

4. Sinnreich M, Therrien C, Karpati G (2006) Lariat branch point mutation in the dysferlin gene with mild limb-girdle muscular dystrophy. Neurology 66(7):1114-1116. "https:// doi.org/10.1212/01.wnl.0000204358. $89303.81^{\prime \prime}$

5. Wein N, Avril A, Bartoli M et al (2010) Efficient bypass of mutations in dysferlin deficient patient cells by antisense-induced exon skipping. Hum Mutat 31(2):136-142

6. Barthélémy F, Blouin C, Wein N et al (2015) Exon 32 skipping of dysferlin rescues membrane repair in patients' cells. J Neuromuscul Dis 2(3):281-290. "https://doi.org/ 10.3233/JND-150109"

7. Bansal D, Miyake K, Vogel SS et al (2003) Defective membrane repair in dysferlin-deficient muscular dystrophy. Nature 423(6936): $168-172$ 